$\begin{array}{lll}\text { KULTURA } & \begin{array}{l}\text { POLSKA AKADEMIA NAUK } \\ \text { KOMITET SOCJOLOGII }\end{array} & \text { ISSN 0023-5172 } \\ \text { i } & \begin{array}{l}\text { INSTYTUT STUDIÓW POLITYCZNYCH } \\ \text { SPOLCZENSTWO nr 4 }\end{array} & \text { W STRONĘ PRZESZłOŚCI }\end{array}$

ZUZANNA BOGUMIE

Akademia Pedagogiki Specjalnej im. Marii Grzegorzewskiej

\title{
KONFLIKTY PAMIĘCI? - O INTERPRETACJACH HISTORII GUŁAGU
}

Reportaż Georga Reszle i Andreasa Mausa Wolontariusze w stalinowskim Gułagu. Młodzi Niemcy odnawiaja rosyjski obóz karny opowiada o grupie niemieckiej młodzieży, która lato spędza na pracy przy rekonstrukcji drewnianego ogrodzenia łagru Perm-36, jedynego muzeum-skansenu gułagowskich budynków w Federacji Rosyjskiej (zob. Adler 2004, s. 261-263; Williams 2007, s. 14, 82-84). Z reportażu dowiadujemy się, że praca fizyczna jest ciężka, ale motywacja do pracy silna. Młodzi Niemcy są świadomi zbrodni popełnionych przez III Rzeszę w trakcie drugiej wojny światowej, jednocześnie uważają, że sposób, w jaki Niemcy wzięli na siebie odpowiedzialność za grzechy przodków i tworzą miejsca pamięci swoich ofiar, jest słuszną drogą przepracowania pamięci. Zdają sobie sprawę, że ten proces dopiero rozpoczął się w Rosji, dlatego swoją pracę fizyczną traktują jako rodzaj misji — pokazania, że takie działania są ważne i potrzebne.

W pewnym momencie młodzież dowiaduje się, że jako stróż $\mathrm{w}$ muzeum pracuje Iwan Kukuszkin, były ochronnik łagru Perm-36. Wiadomość ta wywołuje powszechną konsternację. Młodzi Niemcy odmawiają dalszej pracy u boku byłego strażnika, który w ich oczach jawi się jako rosyjski funkcjonariusz SS. Następnego dnia na spotkanie z młodzieżą przyjeżdża Siergiej Kowaliow, cieszący się powszechnym szacunkiem były dysydent i więzień obozu Perm-36. Młodzież zwierza mu się ze swojego oburzenia wywołanego istniejącą sytuacją. Jednak Kowaliow zamiast przyznać im rację wpada w szał mówiąc, że Iwan Kukuszkin jest porządnym człowiekiem, a Niemcy nie mają prawa go osądzać. Takiej reakcji młodzi ludzie się nie spodziewali. Rozmowa urywa się, a następnie wszyscy, w ciszy i w stanie braku wzajemnego zrozumienia, rozchodzą się

Adres do korespondencji: zbogumil@aps.edu.pl 
na spoczynek. Następnego dnia młodzież z rezerwą żegna Kowaliowa wracającego do Moskwy. Kontynuują pracę przy rekonstrukcji ogrodzenia, mimo że już nie uważają jej za sensowną.

Rozważania na temat pamięci Gułagu postanowiłam rozpocząć od przywołania treści reportażu $z$ dwóch powodów. Po pierwsze, by na samym początku zaznaczyć, że dotyczyć one będą spraw, które mimo że na pierwszy rzut oka mogą wydawać się oczywiste, wcale takie nie są. Po drugie, by przypomnieć, że zachodni sposób myślenia może czasami bardziej przeszkadzać aniżeli pomagać w zrozumieniu sposobu, w jaki pamięć Gułagu manifestuje się na terenie Federacji Rosyjskiej. Jak pisze bowiem rosyjski semiolog Borys Uspienski (2001, s. 97-98): „specyficzność kultury rosyjskiej polega właśnie na tym, że jest ona jednocześnie podobna i niepodobna do innych kultur. Dlatego zawsze można opisać kulturę rosyjską przy użyciu tych samych terminów - według tego samego modelu - co w wypadku jakiejkolwiek innej kultury, lecz pewne specyficzne cechy kultury rosyjskiej będą wówczas nieuchronnie ignorowane, pozostaną poza polem widzenia badacza". Te specyficzne cechy kultury rosyjskiej wydały mi się najważniejsze dla zrozumienia tego, w jaki sposób pamięć Gułagu manifestuje się w Federacji Rosyjskiej.

Nie zamierzam tu zatem rozważać, $w$ jakim stopniu to, co się pamięta, jest zgodne $z$ tym, co się wydarzyło. Byłoby to zresztą zadanie niełatwe także $z$ tego względu, że choć łagierna literatura wspomnieniowa jest obszerna, to prac sensu stricto historycznych poświęconych historii Gułagu jest niewiele, a te, które istnieją, ujmują problem $\mathrm{w}$ specyficzny sposób ${ }^{1}$. Z kolei istniejące źródła są fragmentaryczne i w dużej mierze niedostępne. Spróbuję natomiast poszukać odpowiedzi na pytanie: dlaczego aktorzy historyczni konstruują swoją pamięć w taki, a nie inny sposób? (zob. Szacka 2003, s. 7). Interesuje mnie zatem proces formowania pamięci Gułagu, a szczególnie jeden konkretny moment, koniec lat osiemdziesiątych, kiedy przybrał on szczególnie intensywną i wielopoziomową formę.

\section{WYZNACZNIKI RAM PAMIĘCI GUŁAGU}

Koniec lat osiemdziesiątych wydaje się szczególnie interesującym przedmiotem refleksji na temat kształtowania się pamięci Gułagu, gdyż odcisnął on największe piętno na sposobie, w jaki pamięć Gułagu obecnie manifestuje się w Federacji Rosyjskiej. Co prawda, pewne znaczące wypowiedzi dają się zauważyć już wcześniej, w trakcie odwilży za czasów Chruszczowa, kiedy rozpoczął się proces rehabilitacji więźniów (Sherbakova 1998, s. 235-245; Adler 1993,

\footnotetext{
${ }^{1}$ Istniejące publikacje pokazują jedynie fragment łagiernej historii lub stanowią próbę ogólnej, całościowej syntezy historii Gułagu. Mimo że coraz więcej publikuje się zbiorów dokumentów, to prac stanowiących szczegółowe opracowanie historii okręgów łagiernych, nie mówiąc już o historii poszczególnych łagrów i łagpunktów, jest bardzo niewiele.
} 
2004; Smith 1996). Jednak dopiero w odniesieniu do końca lat osiemdziesiątych możemy mówić o kreowaniu zupełnie nowej, wielopoziomowej sytuacji dyskursywnej.

Po pierwsze, dokonywana wówczas rekonstrukcja przeszłości nadała kształt pamięci sowieckich represji. Jak podkreśla Maurice Halbwachs, pamięć jest kształtowana językowo: „Ujmujemy w słowa nasze wspomnienia zanim je przywołamy, tak więc mowa i cały system powiązanych z nią konwencji społecznych pozwalają nam za każdym razem odtworzyć naszą przeszłość" (Halbwachs 1969, s. 407). Pamięć Gułagu przez długi czas istniała poza obszarem dyskusji społecznej, dopiero koniec pierestrojki otworzył pole kształtowania się konwencji, które miały pomóc w zrozumieniu wypowiadanych słów - wspomnień. Ukształtowane wówczas ramy pamięci Gułagu również dziś oddziałują na sposób jego postrzegania.

Po drugie, fakty, miejsca i postacie, które wówczas były przedmiotem dyskusji i artykułów prasowych, współtworzyły to, co jest obecnie rozumiane jako historia Gułagu. Innymi słowy, urastały do rangi jego symbolicznych oznaczników ${ }^{2}$. Pamięć często kumuluje się wokół przedmiotów i miejsc ${ }^{3}$, które są przesiąknięte symbolicznymi asocjacjami z minionymi wydarzeniami i dlatego pozwalają najlepiej zachować pamięć zbiorową (Misztal 2007, s. 385). Ponieważ wypowiedziane w tym okresie wspomnienia stawały się fenomenem społecznym, przedmioty - dowodami historii, a odnalezione cmentarze dziedzictwem przeszłości, pojawiła się konieczność ich społecznej lokalizacji i ochrony (por. Bogumił 2010b, s. 41-56). Odczuwano potrzebę natychmiastowego tworzenia miejsc pamięci, które będą chronić pamięć, oraz znaków pamięci, które będą ją wyrażać.

Było to ogromnie ważne, gdyż przez lata pamięć Gułagu była tłumiona i ulegała społecznemu zapomnieniu. Jeszcze w 1987 r. w całym kraju odbywały się huczne obchody Wielkiego Października, a w muzeach Sołowek, Inty czy Magadanu powstawały wystawy wychwalające osiągnięcia systemu komunistycznego. Rok później nastąpiło pęknięcie w dotychczasowym porządku świata. Historia Gułagu została odkopana z niepamięci i wylała się na powierzchnię w całej swojej niezrozumiałości. Konieczne zatem stało się ogarnięcie tego ogromnego doświadczenia społecznego, które przez sześćdziesiąt lat nie podlegało społecznej obróbce i przepracowaniu.

2 Symboliczne oznaczniki rozumiem w taki sposób, w jaki pisze o nich Dean MacCannell w odniesieniu do świata turystycznego. Oznacznikiem jest wszelka informacja o obiekcie, zarówno ta znajdująca się obok, jak i ta oddzielona od niego. MacCannell szczegółowo tłumaczy sposób funkcjonowania symbolicznych oznaczników na przykładzie postrzegania San Francisco przez turystów. $Z$ jednej strony pojedyncze, wybrane elementy miasta mogą być odbierane jako składniki San Francisco. Z drugiej - każdy z nich może być traktowany jako oddzielny obiekt, interesujący sam w sobie (MacCannell 2002, s. 174-175).

${ }^{3} \mathrm{Na}$ tę zasadę zwrócili już uwagę starożytni Grecy, których interesowała praktyczna strona działania pamięci (Yates 1977). 
Trzeba było znaleźć punkty zaczepienia, które umożliwią zrozumienie tragicznej przeszłości. Okazało się, że wiele dokumentów zaginęło, zostało zniszczonych lub nie ma do nich dostępu. Pozostałości łagiernej infrastruktury również $\mathrm{w}$ większości zostały zniszczone, dlatego nie przemawiały swym widokiem aż tak silnie jak swego czasu pola bitew pierwszej wojny światowej czy miejsca Holokaustu. Ponadto ich geograficzne oddalenie i ograniczona dostępność, skąpa dokumentacja fotograficzna i jej specyficzny charakter (zdjęcia, które się zachowały, to w większości fotografie propagandowe pokazujące świat oczami katów, a nie ofiar czy świadków wydarzeń) sprawiły, że skoncentrowano się na poszukiwaniu świadków. Pisano do nich listy, słuchano ich i to właśnie wspomnienia zaczęły najsilniej kształtować pamięć Gułagu wspomnienia i literatura, takie książki jak Archipelag Gułag Aleksandra Sołżenicyna, Opowiadania kolymskie Warłama Szałamowa czy Stroma droga Eugenii Ginzburg (Sherbakova 1998, s. 235-245). To właśnie literatura zaoferowała najpełniejszy język opisu doświadczenia Gułagu oraz dostarczała tak potrzebnych faktów.

Książki wymienionych autorów są „,najbardziej znanymi i najsilniej oddziałującymi tekstami, które konstruują postsowiecką kulturę pamięci o stalinowskim terrorze" - pisze angielska badaczka literatury łagrowej Adi Kuntsman (2009, s. 326). Fragmenty tych prac były sekretnie publikowane w samizdacie od lat sześćdziesiątych. Cieszyły się wielkim moralnym autorytetem, co więcej „nie były traktowane jako prywatne autobiografie $\mathrm{i}$ indywidualne narracje, ale jako dokumenty mające transcendentalne historyczne znaczenie" (Kuntsman 2009, s. 326). Były postrzegane jako „prawdziwe historie i przeciwstawiano je kłamstwom, przemilczeniom i zniekształceniom, które były konstytutywne dla oficjalnej sowieckiej historiografii" (Kuntsman 2009, s. 326).

Traktowanie wspomnień świadków Gułagu jako bardzo wiarygodnego źródła przekazu historycznego można zrozumieć, jeśli spojrzy się na nie w szerszym kontekście tradycji rosyjskiej literatury. Jak zauważa badaczka tej tematyki Irina Paperno, wiele więziennych wspomnień swoją formą i sposobem budowania narracji przypomina paradygmatyczną dla rosyjskiego pisarstwa autobiograficznego pracę Aleksandra Hercena Rzeczy minione i rozmyślenia. Jego wspomnienia - jak tłumaczy Paperno - są silnie zakorzenione w heglowskim historyzmie, przez co nadają wyjątkowy status autorowi tekstu. Przenika je "duch dziejów” - historia jest bowiem immanentnie obecna w każdym indywiduum i można ją zrekonstruować przyglądając się decyzjom podejmowanym przez jednostkę w życiu codziennym. Jak podkreśla Paperno (2002, s. 577-610), praca Hercena mocno wpłynęła na sposób postrzegania w kulturze rosyjskiej wspomnień świadków. Prawdopodobnie dlatego obecnie na wszystkich wystawach można znaleźć odwołania do Sołżenicyna czy Szałamowa, a przewodnicy $\mathrm{w}$ trakcie zwiedzania traktują informacje zawarte $\mathrm{w}$ ich książkach $z$ taką samą wiarygodnością jak dokumenty znajdujące się $\mathrm{w}$ archiwach historycznych, mimo że wiele jest w tych pracach wątków fikcyj- 
nych ${ }^{4}$. Przywołana argumentacja Paperno pozwala zrozumieć, dlaczego tak się dzieje, choć nie ulega wątpliwości, że takie traktowanie literatury jest problematyczne.

Jak podkreślają badacze literatury, wspomnienia nie są neutralnymi dokumentami historycznymi i dlatego analizując je należy skrupulatnie przyjrzeć się, w jaki sposób konstruują one historię, z jakiej tradycji korzystają ich autorzy i jakie można w nich znaleźć przemilczenia i wyolbrzymienia (Kuntsman 2009, s. 328; Toker 2000). Ponadto wspomnienia świadków zawsze są zdeformowane przez czas, mają silny związek ze współczesnością i tym, w jaki sposób mówi się o danym wydarzeniu. Kiedy rozmawiałam z Iwanem Panikarowem — założycielem stowarzyszenia Poisk Niezakonno Represirowanych w Jagodnoje (Kołyma) — zwracał on uwagę, że w otrzymanych przezeń listach od byłych więźniów wiele wspomnień wydawało się identycznych z tymi z Archipelagu Gułag (por. Sherbakova 1998, s. 113). Trudno powiedzieć, na ile dane doświadczenie było rzeczywiście podobne, a na ile publikowane w tym czasie fragmenty książki wpływały na sposób formułowania własnych wspomnień. Być może zbieżność miała charakter przypadkowy, nie ulega jednak wątpliwości, że w Federacji Rosyjskiej literatura i wspomnienia najsilniej oddziaływały (i nadal oddziałują) na sposób postrzegania gułagowskiej przeszłości.

Drugim ważnym źródłem zasad rozumienia znaczenia historii Gułagu wydaje się oficjalna interpretacja, która istniała od zawsze. W jej świetle więźniowie łagrów byli „wrogami ludu”. Taka wizja zadomowiła się w wyobraźni znacznej części społeczeństwa. Pewne sprzeczne z nią informacje wydobyły się na jaw w czasie odwilży Chruszczowa, mimo to do końca lat osiemdziesiątych Gułag nie stanowił przedmiotu powszechnych dyskusji, był wręcz tematem tabu. Do dnia dzisiejszego, mimo rehabilitacji wielu byłych więźniów i ujawnienia zbrodni sowieckich, można spotkać się z opinią, że w łagrach wiele osób osadzono słusznie.

Wiedza społeczeństwa o Gułagu nie jest zatem klasycznym przykładem działania społecznych ram pamięci, które w miarę upływu czasu kształtują przyjmowaną powszechnie wersję wydarzeń. Istniała, co prawda, wspomniana wcześniej państwowa interpretacja, ale niejako z definicji ze względu na swój autorytatywny charakter nie stanowiła przedmiotu społecznego osądu, krytyki i dyskusji. Miała być przyjmowana a priori. Ci świadkowie, którzy się z nią nie zgadzali, przechowywali historię Gułagu we wspomnieniach. Każdy z nich jednak czynił to oddzielnie, nie następowała $w$ zasadzie wymiana informacji ani społeczna ocena tego, co się wydarzyło. Można zatem powiedzieć, że wszyst-

4 Dotyczy to nie tylko wystaw, ale również wielu publikacji poświęconych historii Gułagu. Jako przykład warto przywołać książkę Gułag Anny Applebaum, która w wielu krajach stała się bestsellerem. W znacznej mierze bazuje ona na wspomnieniach świadków i literaturze. W swojej analizie życia łagrowego Applebaum traktuje dokumenty archiwalne i fragmenty książek Warłama Szałamowa, Eugenii Ginzburg czy Aleksandra Sołżenicyna jako równoprawne źródła historyczne. 
kich łączyła zgoda na społeczne milczenie. Pod koniec lat osiemdziesiątych nastąpiło gwałtowne ujawnienie tego, co było skrywane.

\section{GUŁAG W INTERPRETACJI STOWARZYSZENIA MEMORIAŁ I CERKWI PRAWOSŁAWNEJ}

Pod koniec lat osiemdziesiątych pojawiło się wielu aktorów społecznych pretendujących do wyznaczania ram pamięci Gułagu. Skupię się jednak na działaniach i projektach stworzonych przez Stowarzyszenie Memoriał i Cerkiew prawosławną, gdyż - jak pokażę - to właśnie te instytucje w sposób najbardziej aktywny uczestniczyły w owym procesie. Moim zdaniem, jedynie zaproponowane przez nie interpretacje łagiernej przeszłości można nazwać dyskursami przeciw-historii w Foucaultowskim znaczeniu tego terminu. Kolejnym ważnym kryterium ich wyboru jest to, że odmiennie objaśniają one gułagowską historię i nadają jej różne znaczenia. Wytworzone przez nie dyskursy przeciw-historii najbardziej różnią się więc między sobą, a wyjaśnienie ich roli i znaczenia wydaje się najbardziej pomocne w odpowiedzi na pytanie: Dlaczego pamięć Gułagu przybrała w Federacji Rosyjskiej taką a nie inną formę?

Koncepcja przeciw-historii wydaje się użyteczna przy wyjaśnianiu rozumienia pamięci Gułagu z trzech powodów.

Po pierwsze - jak wyjaśnia sam Foucault — sowiecki dyskurs „władzy suwerennej" to dawny dyskurs walki ras, który w XIX wieku przekształcił się w dyskurs rewolucyjny, a w XX wieku w ZSRR uległ dalszemu przekształceniu. Ta transformacja jest ukradkowa i „opiera się na mętnych "naukowych" podstawach. Polega na przeniesieniu rewolucyjnego dyskursu walk społecznych na zarządzanie policją, która zapewnia milczącą higienę uporządkowanego społeczeństwa" (Foucault 1998, s. 88). Wróg klasowy jawił się w tym społeczeństwie jako chory, zboczeniec zagrażający jedności państwa. Innymi słowy, francuski filozof tłumaczy, że dyskurs sowiecki nie był — jak głosiły ówczesne władze - historią uciśnionych, ale jedynie zmutowanym starym dyskursem rzymskiej suwerennej władzy. Dlatego dochodzące do głosu pod koniec lat osiemdziesiątych nowe przeciw-historie ( $w$ tym Stowarzyszenia Memoriał czy Cerkwi prawosławnej) musiały przede wszystkim wykazać, że był on jedynie kłamstwem i iluzją po to, by móc przedrzeć się do świadomości społecznej ze swoją interpretacją przeszłości.

Po drugie, Foucault pokazuje, w jaki sposób w sytuacji braku historycznych nośników pamięci (dokumentów i artefaktów stanowiących współczesną wersję kronik i annałów) ludzie zaczynają tworzyć opowieść o przeszłości. Tłumaczy, że zanim jej elementy przekształcą się w prawdziwe dyskursy historyczne, czerpią z wątków eschatologicznych i mitycznych. To spostrzeżenie wydaje się pomocne $\mathrm{w}$ zrozumieniu działań, jakie w początkowym okresie podejmowały Stowarzyszenie Memoriał i Cerkiew. 
Po trzecie, idąc za sugestiami podsuniętymi przez koncepcję Foucaulta zauważam, że u podstaw formowania się pamięci Gułagu leżało wydobywanie na światło dzienne faktów, które z rozmysłem zostały wypaczone przez dominujący dyskurs.

Trzeba zaznaczyć, że pod koniec lat osiemdziesiątych obok więźniów Gułagu dochodziły do głosu również inne grupy wykluczonych, jak choćby część blokadników Leningradu (Kalendarowa 2006, s. 275-297). Dyskurs sowiecki zacierał ich znaczenie w zwycięstwie oblężenia i tym samym wyłączył $\mathrm{z}$ dyskursu chwały, który można uznać za podstawowy element jednoczący społeczeństwo rosyjskie (zwycięstwo w drugiej wojnie światowej to szczególnie ważny komponent tego dyskursu). Owe pojawiające się różne dyskursy rozumianej po Foucaultowsku przeciw-historii w podobny sposób rozbijały suwerenność państwa (dominację państwowej wizji historii), ale przy tym niweczyły również ciągłość chwały. W tym miejscu warto przytoczyć dłuższy fragment wywodu Foucaulta, który wydaje się pomocny w zrozumieniu omawianego procesu. Jak pisze francuski filozof, kiedy pojawia się przeciw-historia: „Suwerenność nie wiąże już ogółu w jedność, która była właśnie jednością społeczeństwa, narodu, państwa. Suwerenna władza zyskuje szczególną funkcję: nie wiąże, lecz zniewala. Historia jednych nie jest historią drugich. To co dla jednych jest zwycięstwem, dla innych klęską. [...] Przeciw-historia, która rodzi się wraz $z$ opowieścią o walce ras, będzie mówić właśnie o tej stronie cienia, wychodząc $z$ cienia. Będzie dyskursem tych, którzy nie znają sławy albo którzy ją utracili. [...] Ten nowy typ dyskursu [...] zamiast opiewać nieskazitelną chwałę suwerena, skupia się przeciwnie, na opowiadaniu nieszczęść przodków, historii wygnań i niewoli. Dyskurs ten będzie przywoływał nie tyle zwycięstwa, ile klęski, pod którymi uginamy się do dzisiaj, czekając na ziemię obiecaną i na spełnienie obietnic przywracające nam nasze dawne prawa i naszą utraconą sławę" (Foucault 1998, s. 75-76).

Zasadniczym celem dyskursu przeciw-historii zaproponowanego przez Stowarzyszenie Memoriał było właśnie rozbicie władzy suwerennej ZSRR. Przez długi czas był on dyskursem opozycji, stał się narzędziem krytyki i walki z sowiecką formą władzy. Miał na celu pokazanie, „że prawa są zwodnicze, że królowie noszą maski, że władza opiera się na iluzji i że historycy kłamią" (Foucault 1998, s. 77). Ten nowy typ przeciw-historii i jej hasła zaczęły cieszyć się coraz większym społecznym poparciem. Powstała nowa oficjalna wspólnota społeczna - Memoriał, która pomagała w wypowiadaniu i uwalnianiu wspomnień. Ponieważ w chwili wypowiedzenia stawały się one fenomenem społecznym, pojawiła się konieczność ich społecznej lokalizacji i ochrony. Należało powołać do życia miejsca, które będą chronić pamięć i wznosić znaki ją wyrażające, a tym samym współtworzące przestrzeń ujawniania indywidualnego bólu i społecznego oczyszczenia. Wierzono, że dokonanie takiego refleksyjnego kroku w przeszłość pozwoli ludziom żyjącym w czasach rozpadającego się systemu sowieckiego budować lepszą przyszłość. Przystąpiono 
zatem do stawiania znaków pamięci i wyznaczania dat świąt nowego społeczeństwa obywatelskiego (np. 30 października uznano za Dzień Ofiar Represji Politycznych) ${ }^{5}$.

Początkowo planowano wzniesienie wielkich kompleksów memorialnych i muzeów Gułagu na terenie byłych łagrów, a także w Moskwie. Całość miały uzupełniać tzw. szlaki oczyszczenia, którymi ludzie podróżowaliby, tak jak pielgrzymi nawiedzają miejsca święte. Najważniejszy kompleks, jaki miał powstać: Trójkąt Cierpienia i Odkupienia, zaprojektował Ernst Nieizwiestny. Miał on składać się z pomników-masek stojących w Jekaterynburgu, Workucie i Magadanie. Powodem wyboru Jekaterynburga był fakt, że tam rozstrzelano cara Mikołaja II, co stało się początkiem rosyjskiej „biedy” XX wieku i zapoczątkowało okres sowieckich represji. Stojący na granicy Azji i Europy monument byłby jakby „punktem przejścia, bramą Gułagu”. Z kolei pomniki stojące w Workucie i Magadanie symbolizowałyby dwa okryte najgorszą sławą łagierne centra Gułagu $^{6}$. Podstawową funkcją ideologiczną tych trzech powiązanych ze sobą monumentów było nakreślenie ram nowego społeczeństwa demokratycznego.

Fakt, że to właśnie Ernst Nieizwiestny miał stać się autorem wyznaczenia nowego axis mundi ${ }^{7}$, nie był przypadkowy. Stworzony wcześniej przez rzeźbiarza nagrobek Chruszczowa na Cmentarzu Nowodziewiczym w Moskwie przez lata pełnił funkcję symbolu sprzeciwu wobec Stalina. Represjonowani przychodzili tutaj kłaść kwiaty, uważając ów pomnik za symbol protestu politycznego (Leoig

5 W październiku 1974 r. Andriej Sacharow na konferencji prasowej w Moskwie ogłosił, że 30 października będzie Dniem Więźniów Politycznych, Dniem Walki i Wolności. W kolejnych latach w tym dniu więźniowie polityczni przetrzymywani w obozach organizowali głodówki, wydawali również specjalne gazety. Wybór 30 października nie był przypadkowy. Chodziło o to, żeby data nie wiązała się $z$ żadnym innym ważnym politycznym i historycznym wydarzeniem i w ten sposób nie konotowała znaczeń i nie wywoływała wątpliwości. 18 października $1991 \mathrm{r}$. dzień 30 października stał się oficjalnym świętem państwowym. Nazwa tego święta została jednak zmieniona na Dzień Ofiar Represji Politycznych (Grabinowa 2007).

6 Dla wszystkich trzech monumentów przewidziano formę masek. W Jekaterynburgu miały to być dwie maski, o europejskich i azjatyckich rysach, spoglądające $\mathrm{w}$ przeciwnych kierunkach. Workucką maskę, kształtem przypominającą wyspę, planowano wybudować na brzegu rzeki. Z kolei magadańska Maska Bólu miała spoglądać smutnym wzrokiem w stronę Wrót Kołymskich, przez które przypływały statki z więźniami. Ernst Nieizwiestny planował, że wszystkie trzy pomniki zostaną wykonane $z$ tego samego surowca - betonu, dodatkowym elementem je łączącym miały być motywy ognia (słońca) i wody (łez) - symbole zniszczenia i wiecznej pamięci (Leoig 1998, s. 67-71).

7 Jak pisze Mircea Eliade, w społeczeństwach tradycyjnych axis mundi oznacza środek świata „wokół tej osi świata rozciąga się „świat” (= nasz świat), oś oznacza więc zarazem „środek świata”, znajduje się w „pępku ziemi”, stanowi centrum świata”. Wpływa na zachowania człowieka wobec „przestrzeni, w której się żyje”. „Uniwersum rodzi się ze swego centrum, tworzy się wokół punktu środkowego, który stanowi jego "pępek»". Dlatego jego wyznaczenie jest tak ważne, to ono nadaje światu całościowy i uporządkowany kształt — powiada Eliade (1999, s. 29-30, 35). Podobnie ważne było wyznaczenie przez wspólnotę demokratyczną axis mundi nowej Rosji - czyli symbolicznego środka kształtującego system wartości i wpływającego na rozumienie świata. 
1998, s. 69). W ten sposób rzeźbiarz okazał się prekursorem świeckiego języka przedstawienia pamięci Gułagu.

Sytuacja społeczno-polityczna w Związku Radzieckim ulegała wówczas ciągłym zmianom, aby więc uczynić z pamięci Gułagu ważny komponent nowej tożsamości narodowej, należało szybko wybudować pierwsze znaki pamięci. Ponieważ wzniesienie gigantycznych kompleksów wymagało $\mathrm{czasu}^{8}$, postanowiono postawić znaki czasowe, które tu i teraz służyłyby rytuałom pamięci i kształtowały stosunek do przeszłości. Nie przywiązywano dużej wagi do ich formy, chodziło o postawienie uniwersalnych i dobrze zrozumiałych znaków pamięci, tym bardziej że $z$ czasem miały zostać zastąpione przez kompleksy memorialne.

W tym okresie powstały również pierwsze wystawy historyczne, mające na celu zaspokojenie społecznej ciekawości oraz zapoznanie odbiorców z dziejami i problematyką Gułagu. Prezentowane materiały musiały składać się na spójną opowieść, dlatego konieczne było wyznaczenie ram narracji. Ponieważ kwestie związane $z$ tą tematyką nie były rzetelnie opracowane ani poddane głębszej refleksji wolnej od sowieckiej ideologii, znajdowane materiały zaczęto dopasowywać do istniejącej sowieckiej narracji (Bogumił 2009, s. 298-310; Makhotina 2010, s. 85-93). Doskonałym przykładem takich narracji są muzea krajoznawcze Republiki Komi. Mimo przemian, jakie zaszły po roku 1991, cały czas odzwierciedlają one, swą niegdysiejszą, sowiecką misję — podtrzymanie mitu o oswajaniu Północy i skoku cywilizacyjnym, jaki dokonał się wraz z dojściem do władzy sowietów. Łagier, co prawda, nie stanowi już tematu tabu, ale przedstawia się tylko te jego elementy, które wpisują się w historię kulturalnego i przemysłowego rozwoju regionu. Ponadto mówienie o tragicznych wydarzeniach w żaden sposób nie burzy opowieści o oswajaniu Północy (por. Bogumił 2010a).

$\mathrm{W}$ tym samym czasie pojawił się jeszcze drugi typ ważnej przeciw-historii zaproponowany przez Cerkiew prawosławną, będący typową mityczno-religijną interpretacją historii. Odwoływał się on do wielkiej biblijnej formy proroctwa i obietnicy (Foucault 1998). Cerkiew postrzega okres represji sowieckich jako okres prześladowań za wiarę i moment próby. $\mathrm{Ci}$, którym udało się wytrwać w wierze i umarli śmiercią męczeńską, stają się fundamentem, na którym współczesna Cerkiew się odradza. Historia nowego męczeństwa i jej znaczenie znajduje wyraz w ikonach nowych męczenników i spowiedników, chramach i krzyżach pokłonnych, które jako tradycyjne sposoby upamiętniania zmarłych zaczynają obecnie składać się na prawosławną infrastrukturę pamięci Gułagu ${ }^{9}$.

\footnotetext{
${ }^{8}$ Z projektowanego Trójkąta Cierpienia Ernsta Nieizwiestnego udało się wznieść jedynie Maskę Bólu w Magadanie.

$9 \mathrm{~W}$ innych krajach byłego bloku wschodniego narodowo-religijna interpretacja okresu rządów komunistycznych również cieszy się dużą popularnością, a język upamiętniania podobnie wykorzystuje konfesyjne symbole. Jak zauważają Gabriela Cristea i Simina Radu-Bucurenci analizując rumuńskie muzea i pomniki poświęcone komunistycznej przeszłości: „okres od 1945 do 1989 był czasem «sowieckiego zniszczenia», kraj był wówczas kierowany przez reżim polityczny,
} 
W ten sposób Cerkwi prawosławnej udało się stworzyć spójną i wielopłaszczyznową interpretację, która żadnego z pytań o sens Gułagu nie pozostawia bez odpowiedzi (Bogumił 2010a). Prawosławna interpretacja stała się całościowym systemem objaśniającym, a jej społeczną atrakcyjność można również wytłumaczyć przez odwołanie do Foucaultowskiego modelu przeciw-historii.

Dyskurs przeciw-historii wiąże się $z$,teorią binarnego podziału społeczeństwa i ludzi: $z$ jednej strony jedni, $z$ drugiej strony pozostali, niesprawiedliwi i sprawiedliwi, panowie i ci, którzy stali się poddanymi, bogaci i biedni [...] ludzie dzisiejszego prawa i ludzie ojczyzny mającej dopiero nadejść" (Foucault 1998, s. 79). Na gruncie rosyjskim ten binarny ze swej natury dyskurs spotkał się z typem kultury, którą Jurij Łotman (1999) nazywa binarną. „Łotman - jak pisze we wstępie do polskiego wydania jego książki Bogusław Żyłko (1999, s. 23) - skłonny jest przypisać ten fakt specyficznym trwałym właściwościom kultury rosyjskiej, do których należy między innymi jej zasadnicza dwubiegunowość, wyrażająca się w dwoistej naturze jej struktury. Wszystkie podstawowe wartości kulturowe rozkładają się w dwubiegunowym polu, ostro oddzielone od siebie i pozbawione neutralnej sfery aksjologicznej”. Gdy zatem „binarny” dyskurs przeciw-historii natknął się na kulturę o podobnej strukturze, nastąpiło jego wzmocnienie i utwierdzenie.

Warto jednak pamiętać, że każdy dyskurs przeciw-historii ma strukturę binarną, interpretacja historii zaproponowana przez Memoriał miała więc taką samą szansę powodzenia co prawosławna. Co więcej, nikomu nie zależało na poszukiwaniu nowych winnych i na kolejnym podziale społeczeństwa na dobrych i złych ${ }^{10}$. Memoriał chciał jedynie osądzić władzę, a tak naprawdę zależało mu na tym, by ona sama się oczyściła. Cerkiew prawosławna natomiast uważała, że osąd leży w gestii Boga.

Sukces prawosławnej przeciw-historii nie polega zatem na tym, że piętnuje ona winnych represji. Jest on konsekwencją odrodzenia rosyjskiej tożsamości narodowej, które nastąpiło w wyniku demokratycznej rewolucji lat osiemdziesiątych. Ta nowa tożsamość narodowa ma stanowić spoiwo współczesnej

który przybrał postać "czerwonego szatana». Ci, którzy z nim walczyli, ofiary, «oddali swoje życie Chrystusowi, za godność i wolność narodu». Wydaje się, że jedynie symbole chrześcijańskie mają wystarczającą moc, by przeciwstawić się "czerwonemu szatanowi». Ten narodowo-martyrologiczny dyskurs [...] wykorzystuje opozycje: Chrystus-szatan, porządek-nieład, światło-ciemność" (Cristea, Radu-Bucurenci 2008, s. 284).

10 Warto tu zaznaczyć, że w trakcie rewolucji antykomunistycznej (koniec lat osiemdziesiątych) hasła demokratyczne (głównie głoszone przez Memoriał) i narodowe (wykorzystywane przez Cerkiew) pojawiały się jednocześnie, ich rozejście nastąpiło dopiero później. Jak zauważa Carol Barner-Barry (1999, s. 101), powołując się na słowa Richarda Sakwy, znanego brytyjskiego badacza rosyjskiego i europejskiego komunizmu, pod koniec lat osiemdziesiątych hasła narodowościowe były używane przez antykomunistów jako narzędzie mobilizacji społecznej. Demokracja i nacjonalizm uzupełniały się $\mathrm{w}$ walce $\mathrm{z}$ komunizmem, a zasadnicze różnice między nimi pojawiły się dopiero w sytuacji postkomunistycznej. 
Federacji Rosyjskiej (Barner-Barry 1999, s. 101). Prawosławna interpretacja łagiernej przeszłości odgrywa istotną rolę w owym tworzeniu tożsamości, włączona w proces budowania wspólnoty — nikogo nie piętnuje, ale stanowi ważny element jednoczący nową wspólnotę narodową składającą się z prawosławnych Rosjan. Stąd atrakcyjność społeczna tej przeciw-historii.

Ważnym komponentem prawosławnego dyskursu jest de facto obietnica ostatecznego zwycięstwa. Nie każe on bowiem wyrzec się całej sławy przeszłości, dowodząc raczej, że ofiary były potrzebne, a więc i sensowne; pozwala zrehabilitować wszystkich niewinnie zmarłych, interpretując cierpienie i śmierć jako poniesione w imię wiary i wyższych wartości. Żywym natomiast pokazuje, że ich męczeństwo i bieda również nie były bezsensowne. W tym ujęciu są to elementy dyskursu nowej chwały, którą obecnie budują społeczeństwo wraz $z$ nową władzą.

Sądzę, że przedstawiona przeze mnie argumentacja tłumaczy większą społeczną atrakcyjność prawosławnej przeciw-historii. Pokazuje również, dlaczego działania Cerkwi znajdują poparcie współczesnych władz państwowych, a projekty Memoriału, które podkreślają represyjność państwa wobec swoich obywateli, nie. Co więcej, także interpretacja zmian, jakie dokonały się w trakcie rewolucji demokratycznej, wyraźnie wskazuje, że w Federacji Rosyjskiej tak naprawdę nie doszło do przekształcenia władzy, a jedynie do kolejnej zmiany suwerena. Prawosławny dyskurs przeciw-historii jedynie powierzchownie zmienił dawny państwowy dyskurs władzy, nie zniszczył jednak jego podstaw i przyczynił się do kolejnej jego mutacji.

Mieszkańcy Federacji Rosyjskiej, czyniąc z zaproponowanej przez Cerkiew przeciw-historii dominujący dyskurs Gułagu, przypominają swoim działaniem pokonanych przez Spartan w wojnie peloponeskiej Ateńczyków, którzy zdecydowali, że dzień, w którym ponieśli klęskę, nie powinien istnieć (Noushi 2006, s. 52-53). Rosjanie wolą postrzegać się jako naród wybrany, predestynowany do wyższych zadań, a nie jako ofiarę. Jest to strategia zrozumiała; jak podkreśla Otto Gerhard Oexele (2006, s. 17), każda kultura czy grupa ludzka, aby istnieć, musi zyskać punkty odniesienia, a więc pewne momenty historii pamiętać, inne zapomnieć. Co więcej, jak zauważa Jan Assmann (2008, s. 46-47): „Każda społeczność, która postrzega siebie jako lud czy naród, odróżniając się w ten sposób od innych ludów i narodów, "W pewnym sensie» wyobraża sobie samą siebie jako naród wybrany". Dlatego prawosławna interpretacja, która nie tylko wychodzi naprzeciw tym oczekiwaniom, ale jednocześnie znajduje swoją legitymizację w kulturze rosyjskiej, wydaje się tak atrakcyjna.

Podczas gdy Cerkwi udało się wytworzyć spójny prawosławny język interpretacji doświadczenia Gułagu (operujący takimi pojęciami jak „nowi męczennicy”, „prześladowania za wiarę”, „Golgoty Rosji”) i jego przedstawiania (z wykorzystaniem takich materialnych znaków jak ikony czy chramy), Memoriał nie zdołał wypracować spójnego świeckiego języka. Obrazem tego niepowodzenia mogą być niezrealizowane projekty wykreowania kompleksowych 
materialnych krajobrazów pamięci. Z powodu kryzysu ekonomicznego połowy lat dziewięćdziesiątych, dewaluacji rubla, galopującej inflacji i dokonujących się przemian społecznych wzniesienie kompleksów memorialnych - trudne ze względu na założenia architektoniczne - stało się wręcz niemożliwe. Analizując te niezrealizowane projekty odkrywamy "pamięć nieuwiecznioną”, ale wciąż żywą w umysłach ludzi, którzy brali udział w ich projektowaniu. Same w sobie stały się one elementem pamięci Gułagu czy może lepiej powiedzieć - pamięci pamięci Gułagu.

Jednak to nie kryzys ekonomiczny wydaje się główną przyczyną fiaska kreowania świeckiego języka przekazującego doświadczenie Gułagu i jego historię. Mimo podjętych prób Memoriałowi nie udało się powołać do życia nasyconego znaczeniami systemu, który wyznaczyłby ramy nowej wspólnoty obywatelskiej (zarówno w aspekcie czasowym - święta, jak i przestrzennym - miejsca pamięci) i zawierał próbę odpowiedzi na pytania: „Dlaczego Gułag był możliwy? Jak dalej mamy żyć?”. Jak zauważa rosyjski badacz Aleksander Etkind (2004, s. 51-52): „W Rosji nie odbyła się poważna filozoficzna debata, ani świecka, ani religijna, poruszająca problem winy, pamięci i tożsamości społeczeństwa, które przeszło przez masowy terror". Co prawda, na początku lat dziewięćdziesiątych Dimitrij Lichaczew próbował inicjować tego typu dyskusje, jednak jak pisze Etkind (2004, s. 52): „Rosyjska inteligencja nie wydała pracy podobnej do znakomitej rozprawy Karla Jaspera Problem winy, która w niemieckim społeczeństwie wywołała niecichnące debaty".

Nie oznacza to, że Memoriał nie szukał odpowiedzi na te pytania. Początkowo odwoływał się do argumentacji wypracowanych przez badaczy systemów totalitarnych. Jak zauważa Aleksiej Miller (2001, s. 46): „W [rosyjskiej - Z.B.] opinii publicznej późnych lat osiemdziesiątych dominował dyskurs o totalitarnej naturze rządów komunistycznych. Początkowo opierał się nie na akademickich dywagacjach, lecz głównie na powieściach Orwella i Zamiatina. [...] W ciągu kolejnych czterech, pięciu lat przetłumaczono na rosyjski niemal wszystkie najważniejsze prace klasyków problematyki totalitaryzmu: Richarda Pipesa, Roberta Conquesta i Martina Malii. Znalazły one szerokie grono czytelników". Koncepcja totalitarna tłumaczyła to, co się wydarzyło w ZSRR, przez analogię do systemu nazistowskiego. Na poziomie funkcjonowania państwa ta interpretacja wydaje się satysfakcjonująca, gdy jednak przechodzi się do kwestii przestępstw popełnianych przez pojedynczą jednostkę, panuje mniejsza zgoda co do tego typu porównań. Jak ocenił jeden $z$ moich rozmówców ludzi pracujących jako wachta w łagrach: to nie byto gestapo. Tu byli różni ludzie ${ }^{11}$. Następnie tłumaczył, że znajdowali się wśród nich sadyści, ale także oficerowie, którzy ryzykowali własne kariery i wolność, wynosząc na zewnątrz zapiski więźniów, na przykład wiersze ukraińskiego poety Wasyla Stusa.

11 [2_WS] - pracownik Muzeum Perm-36, wywiad nieautoryzowany, Kuczino (Perm-36), lipiec 2008. 
Z jednej strony fakt, że wielu oprawców stało się ofiarami systemu, z drugiej lęk przed tym, że jeśli uzna się, iż istnieje grupa winnych, to zacznie się okres porachunków, które na nowo podzielą społeczeństwo, sprawiły, że porównanie systemu sowieckiego $z$ nazistowskim często powoduje więcej nieporozumień, niż pomaga w zrozumieniu. Przywołany przed chwilą przykład wynoszenia przez strażników więziennych notatek doskonale obrazuje ten problem. Oficerowie wynosili zapiski byłych więźniów, a obecnie ci więźniowie, opisując swoje łagierne historie, nie chcą ujawniać ich nazwisk (w ten sposób pragną ich chronić przed potencjalnym atakiem byłych funkcjonariuszy NKWD). Trwa między nimi rodzaj indywidualnej, intymnej relacji opartej na wspólnym doświadczeniu i zaufaniu (Sherbakova 1992, s. 109-110). To specyficzne funkcjonowanie relacji ofiara-oprawca wydaje się znaczącym elementem doświadczenia Gułagu. Sprawia również, że niegdysiejsi dysydenci nie są skłonni do uznania za problematyczny faktu, iż na terenie muzeum Perm-36 jako strażnik pracuje Iwan Kukuszkin, strażnik dawnego łagru. Jak mówił mój rozmówca: żaden $z$ bytych więźniów nie ma jakichkolwiek pretensji do Iwana Kukuszkina [...] miat on za zadanie utrzymanie porządku [2_WS]. Jednocześnie podkreślił, że Kukuszkin jedynie wykonywał swoją pracę, nie znęcał się nad więźniami, a obecnie jest dobrym i solidnym pracownikiem. Co więcej, w trakcie spotkania na wolności to byli więźniowie jako pierwsi wyciągali do niego dłonie na przywitanie (Czerepanowa 1998). Powoduje to konsternację u wielu przyjezdnych z Zachodu, którzy swoją wiedzę na temat nazistowskich obozów koncentracyjnych przekładają na rozumienie Gułagu ${ }^{12}$. Jednocześnie wskazuje, że koncepcja totalitarna rzeczywiście nie umożliwia pełnego zrozumienia łagiernego doświadczenia.

Ważną przeszkodą $\mathrm{w}$ wytworzeniu świeckiego języka opisu wydaje się również fakt, że do opisu doświadczenia Gułagu stosowano pojęcia wypracowane przez sowiecką propagandę. Jak wiadomo, większości wydarzeń, którym chce się przypisać specjalne znaczenie, nadaje się odpowiednią nazwę, która ma to znaczenie wyrażać. Dotyczy to wojny napoleońskiej, którą w Rosji określa się mianem wojny ojczyźnianej, czy drugiej wojny światowej, nazywanej Wielką Wojną Ojczyźnianą. Zastosowanie pewnych pojęć ma umożliwić przepracowania języka tak, by zmieniła się skala wyrażanych sensów i ujęte zostały nowe wartości. Najlepszym tego przykładem wydaje się wytworzenie odrębnego języka na gruncie dyskursu Zagłady Żydów. Aby zrozumieć bezlitosne mordowanie milionów ludzi podczas drugiej wojny światowej zaczęto używać słowa Holokaust lub Shoah, które miało pomóc w uchwyceniu i zrozumieniu tego, co się

$12 \mathrm{~W}$ trakcie mojego pobytu w młodzieżowym obozie Memoriału rozmawiałam z młodą Niemką, która - podobnie jak bohaterowie wspomnianego na wstępie filmu Wolontariusze $w$ stalinowskim Gułagu — nie mogła zrozumieć, dlaczego były ochronnik łagru pracuje w muzeum. Kiedy chciałam porozmawiać z samym Iwanem Kukuszkinem, początkowo się nie zgodził, do czasu, gdy dowiedział się, że nie jestem z Europy Zachodniej, lecz z Polski. Powiedział, że początkowo udzielał wywiadów wszystkim, ale nie chce już rozmawiać z Niemcami, bo oni go ciągle "oskarżają" i nie próbują zrozumieć. 
wydarzyło. W nazistowskim systemie mordowanie milionów niewinnych ludzi nosiło nazwę „ostateczne rozwiązanie kwestii żydowskiej”. Różnica definicji ma ważne semantyczne znaczenie. Rozpracowując projekt "ostatecznego rozwiązania kwestii żydowskiej” nazistowskie władze stworzyły cały nowy język do opisu tego procesu. Współcześnie powstał jednak inny słownik terminów (trauma, pustka, Zagłada), które pozwalają uwolnić się od języka oprawców i spróbować wyrazić to, co ludzkość zrozumiała z tego doświadczenia i co chce pamiętać.

W odniesieniu do Gułagu ten proces się nie dokonał. Cały czas obowiązują terminy ukute przez sowiecką propagandę. Używa się ich zarówno wtedy, gdy zmierza się do zrelacjonowania pewnych faktów, jak i gdy poszukuje się nowego wzorca ich interpretacji, a społeczną pamięć próbuje poddać krytycznej refleksji. Dobrym przykładem jest sposób opowiadania gułagowskiej przeszłości przez przewodników oprowadzających po wystawach historycznych. Kiedy objaśniają oni proces kolektywizacji czy wojenne losy więźniów, używają takich słów jak kułak, piąta kolumna czy wróg ludu. Czasami znacząco patrzą na zwiedzających, dając do zrozumienia, że historyczne (propagandowe) znaczenia tych słów są wątpliwe, przeważnie jednak w żaden sposób nie wskazują na ich znaczeniową problematyczność (por. Bogumił 2009, s. 304).

Warto zauważyć, że słowo „Gułag” nie ma precyzyjnego znaczenia. Używa się go zarówno do określenia funkcjonowania instytucji państwowej, do opisu doświadczenia więźniów, jak i wówczas, gdy konceptualizuje się pamięć tamtych wydarzeń. W tym ostatnim kontekście termin ten określa zarówno system przymusowych obozów pracy funkcjonujących w ZSRR od lat dwudziestych do sześćdziesiątych XX wieku, jak i zbrodnie popełnione przez bolszewików w trakcie wojny domowej, kolektywizację, deportacje Litwinów, Łotyszy i Estończyków w latach 1940-1941, okres dysydencki, a czasami nawet zbrodnię katyńską ${ }^{13}$.

Jedynie na gruncie literackim, zwłaszcza w obszarze literatury wspomnieniowej, wytworzyły się pewne pojęcia, które mają pomóc w rozważaniu doświadczenia Gułagu: „Archipelag Gułag”, „Inny Swiat” czy „Nieludzka Ziemia”. Stosuje się również porównania, takie jak Magadan jako „rosyjskie Auschwitz" czy Workuta jako Buchenwald. Te figury retoryczne, jakkolwiek pozwalają uchwycić i wyrazić pewne fragmenty doświadczenia Gułagu, nie są jednak propozycją spójnego języka, który pozwoliłby zrozumieć całą jego złożoność. W przypadku Holokaustu taki język powstawał kilkadziesiąt lat, a jego współczesny kształt jest efektem przemyśleń i dialogu wielu filozofów, artystów, pisarzy i świadków wydarzeń. Wspomnienia świadków i literatura Sołże-

13 Szerokie znaczenie słowa Gułag można odnaleźć na przykład w książkach Anny Applebaum Gułag (2005) czy Dariusza Tołczyka Gułag w oczach Zachodu (2009). Ten ostatni przez "Gułag” rozumie wszelkie zbrodnie popełnione przez władze sowieckie na własnych obywatelach i podbitych narodach, dlatego jednym z problemów poruszanych w jego pracy jest „zbrodnia katyńska”. 
nicyna czy Szałamowa pozwoliły opisać doświadczenie Gułagu, ale nie stanowią klucza do znalezienia odpowiedzi na wspomniane wcześniej kluczowe dla zrozumienia tego doświadczenia pytania: Jak to było możliwe? Jak dalej mamy żyć? Cerkiew prawosławna proponuje na nie odpowiedzi, dlatego jej interpretacja wydaje się bardziej atrakcyjna społecznie ${ }^{14}$.

Jak pisze cytowany już rosyjski badacz Aleksandr Etkind, elicie rosyjskiej nie udało się wybudować „twardych” pomników i doprowadzić do osądzenia władz komunistycznych, dlatego pamięć o terrorze w Rosji funkcjonuje jedynie na poziomie „pamięci miękkiej”, a nie „twardej”. Przez pamięć miękką Etkind rozumie tę, która ma „tekstualny charakter i funkcjonuje w publicznym dyskursie [...] nie jest zależna od państwa i w pełni jest kształtowana przez społeczeństwo obywatelskie" (Etkind 2004, s. 53-54). Z kolei pamięć twarda znajduje się pod kontrolą władzy i przybiera formę długowiecznych, wyrazistych w formie pomników i memoriałów (Etkind 2004, s. 53-54). Obydwa rodzaje pamięci są ze sobą ściśle związane, jednak nawet głęboka transformacja dokonana na gruncie pamięci miękkiej (jak działo się to w końcu lat osiemdziesiątych i na początku dziewięćdziesiątych) nie oznacza, że stanie się ona „twarda”. Można zatem powiedzieć, że problem z pamięcią Gułagu w Federacji Rosyjskiej nie polega na tym, że mieszkańcy tego kraju zapomnieli o terrorze, ale na tym, że pamięć o nim nie stała się elementem pamięci kształtowanej i chronionej przez państwo.

Współczesną przeszkodą w formowaniu owej pamięci twardej i wznoszeniu pomników, które wyrażałyby świeckie idee, motywując do kontynuowania debaty, stało się również zaostrzenie stosunku państwa do działalności Stowarzyszenia Memoriał. Podczas gdy Borys Jelcyn wspierał budowę Maski Bólu $\mathrm{w}$ Magadanie, $\mathrm{w}$ dużej mierze finansując ją z własnych pieniędzy (na przykład z honorarium za książkę), ekipa Władimira Putina uważa Memoriał za środowisko antyrządowej agitacji ${ }^{15}$.

Jak powiedział jeden $z$ byłych więźniów Workuty i były członek tamtejszego Memoriału: Teraz nie można postawić tych pomników, ale za pięć, dziesięć lat uda się. Chodzi tylko o to, żeby do tego czasu pamięć nie zgasła [...]. Skoro nadszedt czas kiedy przewieziono zwłoki cara czy Denikina, przyjdzie również czas na pomniki

14 Aleksander Sołżenicyn wspierał właśnie narodowo-prawosławną drogę odradzania Federacji Rosyjskiej. Warto w tym miejscu zauważyć, że sposoby postrzegania jego osoby w Federacji Rosyjskiej i na Zachodzie się różnią. Na Zachodzie stał się on jednym z najbardziej znaczących dysydentów, którzy swoją pracą przyczynili się do rozpadu ZSRR. W podobny sposób był postrzegany w kraju przez środowisko Memoriału w momencie rozpadu ZSRR, kiedy wrócił z przymusowej emigracji. Nie był on jednak zwolennikiem zaszczepienia w Rosji zachodniego modelu demokracji i wielokrotnie występował przeciwko niemu, głosząc, że Rosja powinna iść własną drogą i czerpać ze swojej tradycji. W ostatnich latach życia pisarz wspierał politykę prezydenta Putina. Na temat kontrowersji wokół poglądów Sołżenicyna zob. Berman 1980.

15 Przykładem takiego nastawienia może być rewizja dokonana jesienią 2008 r. w siedzibie Memoriału w St. Petersburgu pod pretekstem szukania związków Stowarzyszenia z krytykującą rząd gazetą „Nowyj Pieterburg” (http://www.gazeta.ru/social/2008/12/04/2904026.shtml). 
Gułagu [2_WK] ${ }^{16}$. Tym spostrzeżeniem chciałabym zakończyć rozważania na temat pamięci Gułagu w Federacji Rosyjskiej. Wydało mi się ono ważne, gdyż daje pewną szansę na ponowne rozbudzenie pamięci represji sowieckich jak twierdzi bowiem Walter Benjamin — „nawet najmniejsza cząstka, która ocalona została $\mathrm{w}$ historycznym przekazie, może pewnego razu posłużyć do przełamania obrazu przeszłości, jej konstrukcji, być może zbyt jednostronnej i dlatego niepoprawnej" (Oexle 2006, s. 17).

\section{BIBLIOGRAFIA}

Adler Nanci D., 1993, Victims of Soviet Terror: The Story of the Memorial Movement, Praeger Publishers, Westport.

Adler Nanci D., 2004, The Gulag Survivor: Beyond the Soviet System, Transaction Publishers, Edison.

Applebaum Anne, 2005, Gułag, tłum. Jakub Urbański, Świat Książki, Warszawa.

Assmann Jan, 2008, Pamięć kulturowa. Pismo, zapamiętywanie i polityczna tożsamość w cywilizacjach starożytnych, tłum. Anna Kryczyńska-Pham, Wydawnictwa Uniwersytetu Warszawskiego, Warszawa.

Barner-Barry Carol, 1999, Nation Building and the Russian Federation, w: Betty Glad, Eric Shiraev (red.), The Russian Transformation: Political, Sociological and Psychological Aspects, St. Martin's Press, New York.

Berman Ronald (red.), 1980, Solzhenitsyn at Harvard: The Address, Twelve Early Responses, and Six Later Reflections, Ethics and Public Policy Center, Washington.

Bogumił Zuzanna, 2009, Miejsca pamięci Gułagu - historia represji sowieckich w muzealnych interpretacjach, w: Piotr Chruścielski, Marcin Owsiński (red.), Konferencja „Od Westerplatte do Norymbergi — druga wojna światowa we wspótczesnej historiografii, muzealnictwie i edukacji” w Muzeum Stutthof (2-5 września 2009 r.), Muzeum Stutthof, Sztutowo.

Bogumił Zuzanna, 2010a, Kresty $i$ kamni: soloweckije simwoly $w$ konstruirowanii pamiati o Gułage, „Neprikosnowiennoj Zapas”, nr 3.

Bogumił Zuzanna, 2010b, Cmentarze Gułagu. Teksty zapomnianej kultury w tłumaczeniu wspótczesnym, w: Anna Sylwia Czyż, Bartłomiej Gutowski (red.), Sztuka cmentarzy w XIX $i$ XX wieku, Wydawnictwo Uniwersytetu Kardynała Stefana Wyszyńskiego, Warszawa.

Cristea Gabriela, Radu-Bucurenci Simina, 2008, Raising the Cross, Exorcising Romania's Communist Past in Museums, Memorials and Monuments, w: Oksana Sarkisova, Peter Apor (red.), Past for the Eyes: East European Representations of Communism in Cinema and Museums after 1989, CEU Press, Budapest-New York.

Czerepanowa Tatiana, 1998, Tajny piermskowo „GUŁAGa”, w: A. Susłow, N. Gaszewa (red.), Gody terrora. Kniga pamiati żertw politiczeskich represji, Zdrawstwuj, Perm.

Eliade Mircea, 1999, Sacrum i profanum: o istocie religijności, tłum. Robert Reszke, Wydawnictwo KR, Warszawa.

Etkind Aleksandr, 2004, Vrema sabirat kamni. Postrewolucjonnaja kultura politiczeskoj skorbi $w$ sowremennoj Rossii, „Ab Imperio”, nr 2.

16 [2_WK] — były więzień Workutłagu i członek Memoriału w Workucie, wywiad nieautoryzowany, nie nagrywany, lecz zapisywany w trakcie rozmowy, St. Petersburg, lato 2006. 
Foucault Michel, 1998, Trzeba bronić społeczeństwa. Wykłady w Collège de France, 1976, tłum. Małgorzata Kowalska, Wydawnictwo KR, Warszawa.

Grabinowa Irina, 2007, 30 oktiabria - dien pamiati i bor'by, „30 oktiabria”, nr 79.

Halbwachs Maurice, 1969, Społeczne ramy pamięci, tłum. Marcin Król, Państwowe Wydawnictwo Naukowe, Warszawa.

Kalendarowa Wiktoria, 2006, Formiruja pamiat, błokada $w$ leningradskich gazietach $i$ dokumientalnom kino $w$ posliewojennyje diesiatilietija, w: Marina Loskutowa (red.), Pamiat o btokadie. Swidietelstwa oczewidcew $i$ istoriczeskoje soznanije obszczestwa, Nowoje izdatielstwo, Moskwa.

Kuntsman Adi, 2009, „With a Shade of Disgust”: Affective Politics of Sexuality and Class in Memoirs of the Stalinist Gulag, "Slavic Review”, nr 2, s. 308-328.

Leoig A., 1998, „Trieugolnik stradaniji” Ernsta Nieizwiestnowo: Magadan, Workuta, Jekaterinburg, w: L. P. Birjukowa (red.), Kotyma. Dalstroj. Gułag. Skorb i sudby, Matierijały nauczno-prakticzeskoj konferenciji, Siewiernyj mieżdunarodnyj uniwiersitiet, Magadan.

Łotman Jurij, 1999, Kultura i eksplozja, tłum. Bogusław Żyłko, Państwowy Instytut Wydawniczy, Warszawa.

MacCannell Dean, 2002, Turysta. Nowa teoria klasy próżniaczej, tłum. Ewa Klekot, Anna Wieczorkiewicz, Muza, Warszawa.

Makhotina Ekaterina, 2010, Vom „Heldenepos” zum „Opferort” und zurück: Gedächtnisorte des Weißmeerkanals im heutigen Russland. Eine Lokalstudie im Medvež'egorsker Rayon, „Jahrbücher für Geschichte Osteuropas”, t. 58, s. 70-99.

Miller Aleksiej, 2001, Komunistyczna przeszłość w postkomunistycznej Rosji, „Res Publica Nowa", nr 7.

Misztal Barbara, 2007, Memory Experience: The Forms and Functions of Memory, w: Sheila Watson (red.), Museums and Their Communities, Routledge, London-New York.

Noushi Marc, 2006, „Une tragédie inexcusable”? Francuskie obrachunki z historia, „Borussia”, nr 37.

Oexle Otto Gerhard, 2006, Pamięć i zapomnienie, „Borussia”, nr 37.

Paperno Irina, 2002, Personal Accounts of the Soviet Experience, „Kritika: Explorations in Russian and Eurasian History", t. 3, s. 577-610.

Sherbakova Irina, 1998, The Gulag in Memory, w: Robert Perks, Alistair Thomson (red.), The Oral History Reader, Routledge, London-New York.

Smith Kathleen E., 1996, Remembering Stalin's Victims: Popular Memory and the End of the URRR, Cornell University Press, Ithaca-London.

Szacka Barbara, 2003, Historia i pamięć zbiorowa, „Kultura i Społeczeństwo”, nr 4.

Tołczyk Dariusz, 2009, Gułag w oczach Zachodu, Prószyński i S-ka, Warszawa.

Toker Leona, 2000, Return from Archipelago: Narratives of Gulag Survivors, Indiana University Press, Bloomington.

Uspienski Boris, 2001, Religia i semiotyka, tłum. Bogusław Żyłko, słowo/obraz terytoria, Gdańska.

Williams Paul, 2007, Memorial Museums, The Global Rush to Commemorate Atrocities, OBERG, Oxford-New York.

Yates Frances Amelia, 1977, Sztuka pamięci, tłum. Witold Radwański, Państwowy Instytut Wydawniczy, Warszawa.

Żyłko Bogusław, 1999, Wstęp, w: Jurij Łotman, Kultura i eksplozja, tłum. Bogusław Żyłko, Państwowy Instytut Wydawniczy, Warszawa. 


\section{CONFLICTS OF MEMORY? \\ ON THE INTERPRETATIONS OF THE GULAG HISTORY}

\section{Sum mary}

Until the end of 1980s, the topic of Soviet persecutions was tabooed in the USSSR. Political and social transitions that took place in that period finally eroded the wall of silence. The stories about Gulag past started to appear in the newspapers and the witnesses finally spoke. The reconstruction of the history of the Gulag, proposed at that time, became the cornerstone of the public memory of this historical experience. In my paper, I use Michel Foucault's concept of anti-history in order to analyse the methods of interpretation and commemorating of these tragic events of the $20^{\text {th }}$ century by the Memorial Society and by the Russian Orthodox Church. It was these two institutions who were the most active in the process of forming the contemporary perception of the Gulag. The interpretations proposed by them are comprehensive constructs that explain the Gulag system in all its complexity. On the basis of materials gathered during field research in Russia, I deconstruct the significance of secular and religious anti-history discourses and analyse their influence on the perceptions of the Soviet persecutions in today's Russia.

\section{Key words/słowa kluczowe}

anti-history / przeciw-historia; memory / pamięć; the Gulag / Gułag; the Memorial Society/ Stowarzyszenie Memoriał; Russian Orthodox Church / Cerkiew prawosławna;, commemoration / upamiętnianie; Soviet persecutions / represje sowieckie 